\title{
Experimental tests of vehicle body accelerations at selected road and rail crossings
}

\author{
Konrad J. Waluś ${ }^{1, *}$, Jakub Polasik ${ }^{1}$, Janusz Mielniczuk ${ }^{2}$, Lukasz Warguła ${ }^{1}$ \\ ${ }^{1}$ Poznań University of Technology, Piotrowo 3, 60-965 Poznań \\ 2 Rail Vehicle Institute Tabor, Warszawska 181, 61-055 Poznań
}

\begin{abstract}
Vehicles moving across the railway are exposed to the dynamic reaction of unevenness of surface on those level crossing. This significantly influences on the increase of the acceleration as well as forces values transferred to the body of the car. These values depend to extent on the geometric parameters of level crossing as well as on the characteristics of the car tires and suspension. The paper presents the results of experimental tests of a small delivery vehicle crossing selected level crossings with a diversified geometric cross-section structure.
\end{abstract}

Keywords: railway crossing, vehicle, car body movement

\section{Introduction}

As the economy and industry develop dynamically we can also observe a growing need for transportation. Currently the most popular and the most available type of transport is the road transport. Owing to the European funds [1] the road network is developing substantially what directly contributes to the increase of number of crossroads with rail transport routes, especially in suburban areas. Such crossroads due to the change of road geometry and introducing transversal unevenness may be called obstacles [2-4]. According to construction rules on a new level crossing the head of the rail should stick out of the surface of the crossing. The detailed data concerning the dimensions of level crossings in Poland are published in $\$ 36.1$ of the decree of The Ministry of Infrastructure and Development from 20th October 2015 about "the conditions to be fulfilled by crossroads of rails and railway side-tracks with the roads and their placement" [5]. The change of surface geometry may substantially influence the road safety $[6,7]$ and the comfort of passengers traveling in a vehicle. In certain cases, rain, snow, ice or rime on a transversal obstacle such as level crossing may cause a lower or even lack of traction of wheels to the surface [8]. Additionally, geometry profile of level crossing determines the longitudinal inclinations of car body solid. The article presents preliminary research of the influence of geometry of selected level crossings on the acceleration of the car body.

\footnotetext{
* Corresponding author: konrad.walus@put.poynan.pl

Reviewers: Juraj Gerlici, Ksawery Szykiedans
} 


\section{Research method}

The aim of the research was the analysis of the three-dimensional system of car body acceleration while driving across a level crossing. The research consisted in intensive acceleration of a small delivery vehicle from a start stop position till obtaining a desired speed, driving across the level crossing and then sudden braking until the vehicle is stopped. The research was conducted during one in order to limit the fluctuation of environmental parameters. During the research eight test drives were performed. In the vehicle there was a driver and a person responsible for the handling of the measurement equipment.

The vehicle was equipped with measurement device produced by Analog Devices company type ADIS 16385 consisting of integrated three - axial gyroscope sensor and three-axial accelerometer. The measurement devices were mounted outside, on the car's roof. The measurement system is mounted in uninvasive way with a use of suction cups. In order to activate and store data a laptop computer was used with a special software dedicated to sensors. The measurement equipment has the characteristics of measurement uncertainty at the level of $2 \%$ [9].

For the research vehicle a global coordinate system connected with the roadway, the vehicle is moving at was assumed. The global coordinate system is defined in the following way that the direction of $\mathrm{X}$ axis is set alongside the axis of the roadway, $\mathrm{Y}$ axis in plane perpendicullary to axis $\mathrm{X}$ and vertical axis $\mathrm{Z}$. The local coordinate system connected with the vehicle is set in accordance with operating standards PN-91/S-02030 and PN-ISO 8855.

\section{Research place}

The three level crossings that were chosen for the road test had differentiated geometry (Fig. 1). In order to define the exact parameters of level crossing geometry the measurements with geodetic total station (TS) were done. A section of road was measured starting from the point where the road tests began, every 5 meters, till the place where the vehicle stopped in the attempt with the longest braking distance.

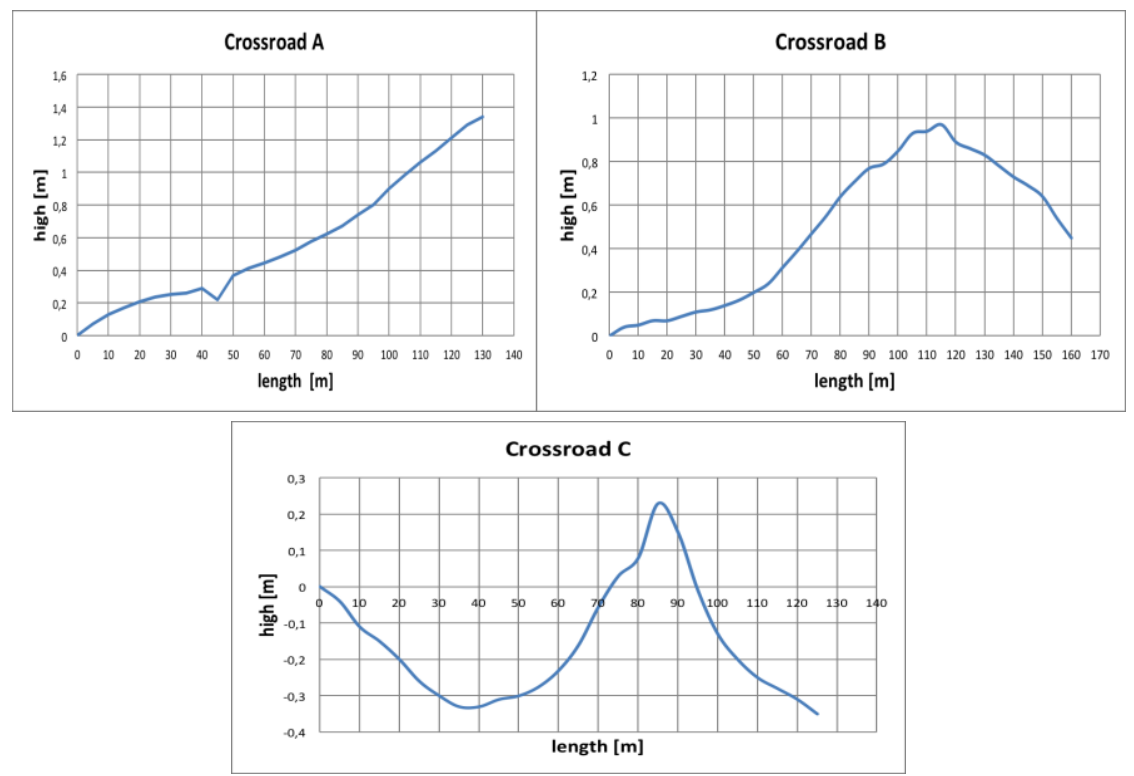

Fig. 1. A view graphs of the tested railway crossings 
The first level crossing chosen for the road tests was the crossroad of an access road with a railway track leading to a nearby industrial plant (crossroad A). Nowadays the rails are no longer used by rail vehicles.

The second level crossing the chosen for the road tests was the crossroad of a road with two rail tracks. The first track is regularly used, whereas the second one is no longer in use. In the past it was a railway side-track leading to a nearby plant (Crossroad B). There is a speed limit at this tested section of the road of $60 \mathrm{~km} / \mathrm{h}$.

The third level crossing was a crossroad with one rail track. It is a rail route located in industrial area (Crossroad C). This level crossing is often crossed by vehicles of total weight exceeding 3.5 tones. There is a speed limit at this tested section of the road of $50 \mathrm{~km} / \mathrm{h}$. The geometrical characteristics of level crossings chosen for the road tests is presented in Figure.

\section{Vehicle characteristics}

The vehicle used for road tests was a delivery vehicle Volkswagen Transporter with front wheel - drive and manual gear box. The car was manufactured in 2011.

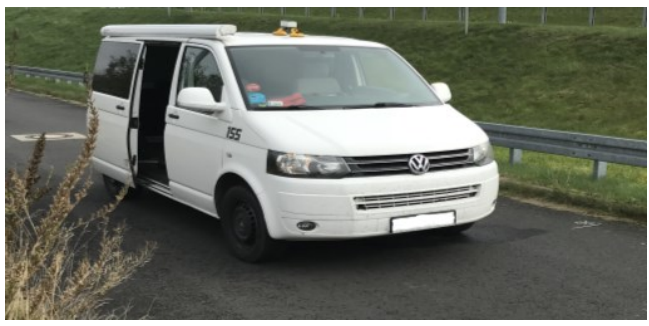

Fig. 2. A view of the VW Transporter test vehicle with installed test equipment

The vehicle was equipped with tires Good Year Marathon Cargo size 235/65 R16C on steel rims. These tires are adapted to carry higher loads in comparison to tires used in passengers vehicles.
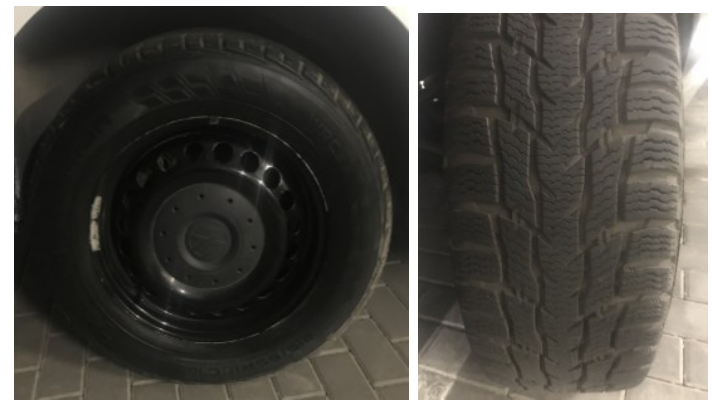

Fig. 3. View of the test vehicle wheel (left), tire tread view (right)

\section{Research results}

All series of test were made from the stopped start position trying to go across the level crossing at a constant speed and starting the braking process after passing the rail tracks. From the obtained accelerations registered by the sensor being the relevant of the vertical axis $Z$ the value of gravitational acceleration of $9.81 \mathrm{~m} / \mathrm{s}^{2}$ was subtracted. The obtained results are presented in Tables below. 
Table 1. Crossroad A

\begin{tabular}{|c|c|c|c|c|c|}
\hline $\begin{array}{c}\text { Total } \\
\text { distance } \\
\text { covered } \\
{[\mathrm{m}]}\end{array}$ & $\begin{array}{c}\text { Time of } \\
\text { trial } \\
{[\mathrm{s}]}\end{array}$ & $\begin{array}{c}\text { The speed of } \\
\text { running into } \\
\text { obstacle } \\
{[\mathrm{km} / \mathrm{h}]}\end{array}$ & $\begin{array}{c}\text { The value of } \\
\text { acceleration } \\
\text { impulse in X axis } \\
{\left[\mathrm{m} / \mathrm{s}^{2}\right]}\end{array}$ & $\begin{array}{c}\text { The value of } \\
\text { acceleration } \\
\text { impulse in Y } \\
\text { axis } \\
{\left[\mathrm{m} / \mathrm{s}^{2}\right]}\end{array}$ & $\begin{array}{c}\text { The value of } \\
\text { acceleration } \\
\text { impulse in Z } \\
\text { axis } \\
{\left[\mathrm{m} / \mathrm{s}^{2}\right]}\end{array}$ \\
\hline 69.267 & 14.832 & 48.449 & 2.882 & 3.684 & -0.021 \\
\hline 69.168 & 14.238 & 50.314 & 2.351 & 3.644 & -0.168 \\
\hline 69.591 & 15.025 & 46.616 & 3.651 & -0.260 & 1.775 \\
\hline 68.941 & 14.395 & 49.478 & 2.332 & 3.934 & -0.337 \\
\hline 69.119 & 16.454 & 48.614 & 2.574 & 0.505 & 0.968 \\
\hline 70.045 & 15.599 & 50.558 & 2.243 & 2.551 & -0.016 \\
\hline 70.495 & 14.555 & 49.579 & 2.202 & -1.582 & 3.231 \\
\hline 69.283 & 14.574 & 47.696 & 2.774 & -0.358 & 1.539 \\
\hline \multicolumn{7}{r|}{ Standard deviation } & 0.482 & 2.185 & 1.251 \\
\hline
\end{tabular}

Table 2. Crossroad B first rail track

\begin{tabular}{|c|c|c|c|c|c|}
\hline $\begin{array}{c}\text { Total } \\
\text { distance } \\
\text { covered } \\
{[\mathrm{m}]}\end{array}$ & $\begin{array}{c}\text { Time } \\
\text { of trial } \\
{[\mathrm{s}]}\end{array}$ & $\begin{array}{c}\text { The speed of } \\
\text { running into } \\
\text { obstacle } \\
{[\mathrm{km} / \mathrm{h}]}\end{array}$ & $\begin{array}{c}\text { The value of } \\
\text { acceleration } \\
\text { impulse in X axis } \\
{\left[\mathrm{m} / \mathrm{s}^{2}\right]}\end{array}$ & $\begin{array}{c}\text { The value of } \\
\text { acceleration } \\
\text { impulse in Y } \\
\text { axis } \\
{\left[\mathrm{m} / \mathrm{s}^{2}\right]}\end{array}$ & $\begin{array}{c}\text { The value of } \\
\text { acceleration } \\
\text { impulse in } Z \\
\text { axis } \\
{\left[\mathrm{m} / \mathrm{s}^{2}\right]}\end{array}$ \\
\hline 132.306 & 16.232 & 50.155 & 8.009 & 1.702 & -0.206 \\
\hline 133.485 & 16.414 & 54.803 & 8.562 & 1.435 & -0.623 \\
\hline 133.285 & 17.071 & 52.513 & 8.111 & 1.773 & -0.056 \\
\hline 134.056 & 17.351 & 52.369 & 7.749 & 1.658 & -0.797 \\
\hline 135.171 & 17.476 & 56.045 & 7.320 & 1.658 & -0.875 \\
\hline 134.363 & 16.194 & 52.945 & 7.966 & 1.594 & -0.939 \\
\hline 133.926 & 16.834 & 55.015 & 8.038 & 2.085 & 0.059 \\
\hline 132.991 & 17.162 & 52.823 & 8.338 & 1.660 & -0.584 \\
\hline \multicolumn{7}{r|}{ Atandard deviation } & 8.012 & 1.696 & -0.503 \\
\hline \multicolumn{7}{r|}{ Stane } & 0.372 & 0.185 & 0.385 \\
\hline
\end{tabular}

Table 3. Crossroad B second rail track

\begin{tabular}{|c|c|c|c|c|c|}
\hline $\begin{array}{c}\text { Total } \\
\text { distance } \\
\text { covered } \\
{[\mathrm{m}]}\end{array}$ & $\begin{array}{c}\text { Time of } \\
\text { trial } \\
{[\mathrm{s}]}\end{array}$ & $\begin{array}{c}\text { The speed of } \\
\text { running into } \\
\text { obstacle } \\
{[\mathrm{km} / \mathrm{h}]}\end{array}$ & $\begin{array}{c}\text { The value of } \\
\text { acceleration } \\
\text { impulse in X axis } \\
{\left[\mathrm{m} / \mathrm{s}^{2}\right]}\end{array}$ & $\begin{array}{c}\text { The value of } \\
\text { acceleration } \\
\text { impulse in Y } \\
\text { axis } \\
{\left[\mathrm{m} / \mathrm{s}^{2}\right]}\end{array}$ & $\begin{array}{c}\text { The value of } \\
\text { acceleration } \\
\text { impulse in Z } \\
\text { axis } \\
{\left[\mathrm{m} / \mathrm{s}^{2}\right]}\end{array}$ \\
\hline 132.306 & 16.232 & 50.638 & 5.038 & 2.303 & 1.295 \\
\hline 133.485 & 16.414 & 52.096 & 5.678 & 3.303 & 2.663 \\
\hline 133.285 & 17.071 & 52.222 & 5.883 & 3.267 & 2.467 \\
\hline 134.056 & 17.351 & 52.358 & 5.900 & 2.325 & 2.183 \\
\hline 135.171 & 17.476 & 56.797 & 5.730 & 2.281 & 2.448 \\
\hline 134.363 & 16.194 & 53.482 & 5.682 & 2.899 & 2.533 \\
\hline 133.926 & 16.834 & 55.584 & 5.904 & 2.609 & 2.394 \\
\hline 132.991 & 17.162 & 52.380 & 6.634 & 2.710 & 2.448 \\
\hline & & Average & 5.806 & 2.712 & 2.304 \\
\hline
\end{tabular}




\begin{tabular}{|r|c|c|c|}
\hline Standard deviation & 0.437 & 0.415 & 0.429 \\
\hline
\end{tabular}

Table 4. Crossroad C

\begin{tabular}{|c|c|c|c|c|c|}
\hline $\begin{array}{c}\text { Total } \\
\text { distance } \\
\text { covered } \\
{[\mathrm{m}]}\end{array}$ & $\begin{array}{c}\text { Time of } \\
\text { trial } \\
{[\mathrm{s}]}\end{array}$ & $\begin{array}{c}\text { The dpeed of } \\
\text { running into } \\
\text { obstacle } \\
{[\mathrm{km} / \mathrm{h}]}\end{array}$ & $\begin{array}{c}\text { The value of } \\
\text { acceleration } \\
\text { impulse in X axis } \\
{\left[\mathrm{m} / \mathrm{s}^{2}\right]}\end{array}$ & $\begin{array}{c}\text { The value of } \\
\text { acceleration } \\
\text { impulse in Y } \\
\text { axis } \\
{\left[\mathrm{m} / \mathrm{s}^{2}\right]}\end{array}$ & $\begin{array}{c}\text { The value of } \\
\text { acceleration } \\
\text { impulse in } Z \\
\text { axis } \\
{\left[\mathrm{m} / \mathrm{s}^{2}\right]}\end{array}$ \\
\hline 54.618 & 9.570 & 42.858 & -9.151 & -0.689 & -3.591 \\
\hline 54.724 & 10.279 & 45.342 & -10.933 & -1.557 & -5.198 \\
\hline 70.407 & 11.175 & 48.028 & -7.221 & 1.020 & -4.766 \\
\hline 64.550 & 10.665 & 49.673 & -7.695 & -0.123 & -4.175 \\
\hline 61.795 & 10.336 & 48.449 & -8.492 & 4.584 & -6.939 \\
\hline 63.744 & 10.323 & 47.686 & -10.125 & 1.972 & -9.232 \\
\hline 65.294 & 10.671 & 49.777 & -8.221 & 3.402 & -8.933 \\
\hline 62.554 & 10.103 & 49.295 & -10.143 & 0.814 & -5.151 \\
\hline \multicolumn{7}{r}{} & Average & -8.998 & 1.178 & -5.998 \\
\hline \multicolumn{7}{r}{ Standard deviation } & -1.313 & 2.070 & 2.136 \\
\hline
\end{tabular}

\section{The analysis of research results}

All the measurement trials were performed unidirectionally. The obtained measurement data underwent mathematical processing in order to separate the influence of gravity on the results.

On the basis of the obtained characteristics of longitudinal accelerations of the vehicle it was possible to determine the momentary values of accelerations that are transmitted on the car body, generated by the interaction of the tire with the obstacle (rail tracks). The results of accelerations obtained during trails and presented graphically in Figure 4.
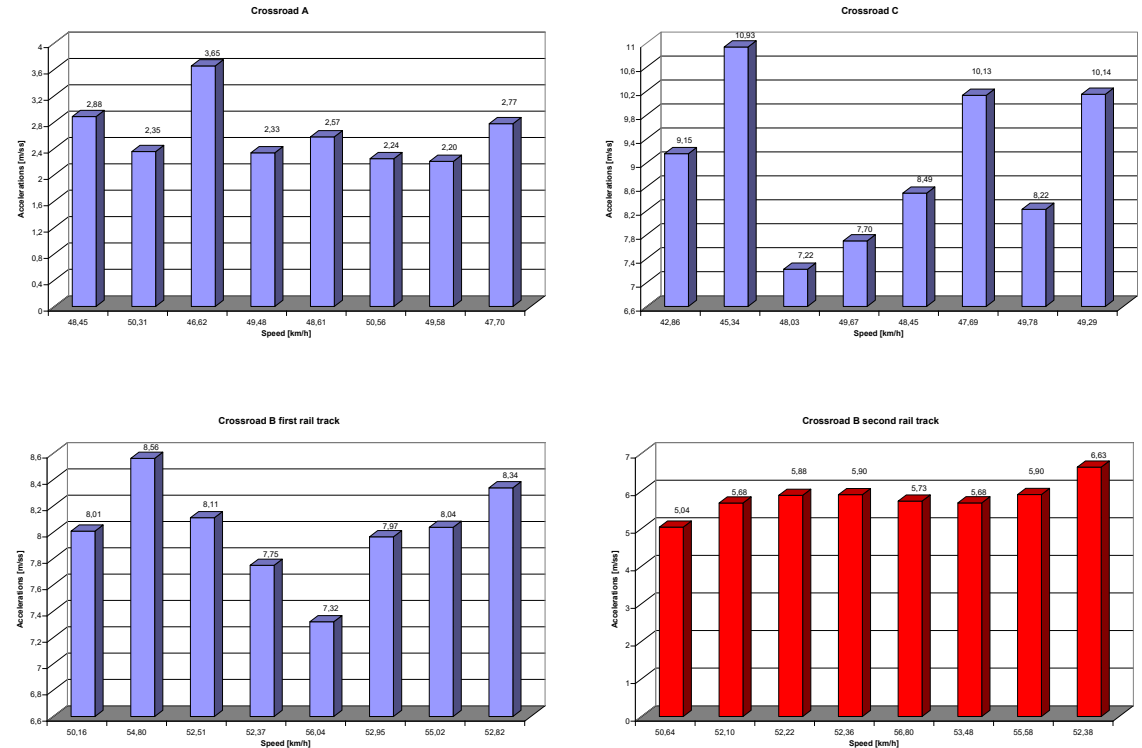

Fig. 4. The value of accelerations in $\mathrm{X}$ axis while crossing chosen level crossings 
Level crossing A had a small but constant inclination. The construction of this level crossing was adjusted to minimize the impact on vehicles moving on the road. The intensivity of interaction of the rail track was insignificant and the obtained accelerations in three axes did not exceed the value of $4 \mathrm{~m} / \mathrm{s}^{2}$.

Level crossing $\mathrm{B}$ because of its geometry generated the values of longitudinal accelerations of over $a_{x}>7 \mathrm{~m} / \mathrm{s}^{2}$ for the first rail track and $a_{x}>5 \mathrm{~m} / \mathrm{s}^{2}$ for the second one. The value of accelerations in $\mathrm{Y}$ and $\mathrm{Z}$ axis did not exceed $3.5 \mathrm{~m} / \mathrm{s}^{2}$.

Level crossing $\mathrm{C}$ could be characterized by the highest differentiation of longitudinal geometry of the road. It caused the occurance of the highest values of accelerations in $\mathrm{X}$ axis that in three trials reached the values of over $10 \mathrm{~m} / \mathrm{s}^{2}$, with the maximum value reaching a $10.933 \mathrm{~m} / \mathrm{s}^{2}$. The values of acceleration impulses in $\mathrm{Y}$ and $\mathrm{Z}$ axis were also significantly higher than the ones obtained during trials on level crossing $\mathrm{A}$ and $\mathrm{B}$.

\section{Summary}

Level crossings are inseparable part of transport infrastructure. The already existing ones and those under construction undergo degradation connected with the changing environmental and exploitation conditions. Changes that occur influence the safety of both rail and road vehicles. Geometry of a vehicle has a direct influence on the acceleration values of car body in dimensional coordinate system.

The carried out research showed a direct relation of vehicle's geometry with obtained acceleration values. The most geometrically even level crossing A has a minor impact on vehicle. It means increased safety on this crossroad and Lower side effects for the suspension system when the tire hits the head of the rail. Level crossing $\mathrm{C}$ had an expanded geometrical profile which mean the occurrence of high value of acceleration impulses while crossing it. This kind of configuration of level crossing generated momentary overloads of value of over 1g. Double rail tracks of level crossing B generated lower values of accelerations than level crossing $\mathrm{C}$ but the accelerations in $\mathrm{X}$ axis reached the maximum value of $8.562 \mathrm{~m} / \mathrm{s}^{2}$.

The preliminary research on vehicles moving cross level crossing contributes to subsequent research connected with the measurement of noise level. The scheduled research concerning the measurement of noise level generated by vehicles moving cross level crossing may contribute to creating criteria of estimating such level crossroads. Integrating the measurements of the range of emitted sound and the values of accelerations connected with tire hitting the rail may contribute to determining the passing speed which has a direct influence on traffic safety. The problem of generating noise on level crossings and introducing it into the environment shows a need of carrying out a further research from the point of view of a road transportation.

\section{References}

1. A. Broniszewska, Rozwój infrastruktury drogowej $w$ Polsce $w$ kontekście wykorzystania funduszy unijnych. Zeszyty naukowe Politechniki Częstochowskiej Zarządzenie Nr 10, 58-68, Częstochowa 2013

2. J. Bohatkiewicz, S. Biernacki, M. Drach, D. Kozłowski, P. Nowak, Zasady uspokajania ruchu na drogach za pomoca fizycznych środków technicznych. Opracowano na zlecenie Ministerstwa Infrastruktury, umowa nr TRD/1/2008 z dnia 05.02.2008 r. 113 p. 
3. J. Polasik, K.J. Waluś, Analysis of force during overcoming the roadblock - the prelimenary experimental tests. Transport Problems 2016, Vol. 11, Issue 1, 113-120, DOI: 10.20858/tp.2016.11.1.11, ISSN 1896-0596

4. K.J. Waluś , J. Polasik, F. Markiewicz, M. Cieślik, J. Adamiec, Badania doświadczalne cech kinematycznych ruchu pojazdu typu ,bus” podczas przejazdu przez przeszkodę. Logistyka 5/2014, 1-8 (2014)

5. Rozporządzeniu Ministra Infrastruktury i Rozwoju z dnia 20 października 2015 r. „,w sprawie warunków, jakimi powinny odpowiadać skrzyżowania linii kolejowych oraz bocznic kolejowych z drogami publicznymi $i$ ich usytuowanie. Akt prawny Dz.U. z 2015r. poz. 1744, Warszawa (2015)

6. P. Drózd, Bezpieczeństwo na przejazdach kolejowo - drogowych. Logistyka 4/2011, 190-198 (2011)

7. P. Smoczyński, A. Gill, Object-Oriented Identification ob. Level Cossings. Transport Means 2017 Proceedings of 21st International Scientific Conference, September 20-22, 2017, Juodkrante Lithuania, Part 1, 48-50, ISSN 1822-296X, i-SSN 2351-7034

8. Z. Lozia, J. Nowakowski, Ocena wpływu nierówności nawierzchni drogi na skuteczność działania hamulców w ruchu prostoliniowym. Zeszyty Naukowe Instytutu Pojazdów 1(40)/2001, Warszawa, 131-156 (2001)

9. Analog Devices - technical data of ADIS16385 